\title{
Combined administration of anisodamine and neostigmine produces anti-shock effects: involvement of $\alpha 7$ nicotinic acetylcholine receptors
}

\author{
Li SUN*, Gu-fang ZHANG\#, Xin ZHANG, Qing LIU, Jian-guo LIU, Ding-feng SU*, Chong LIU* \\ Department of Pharmacology, Second Military Medical University, Shanghai 200433, China
}

\begin{abstract}
Aim: To evaluate the anti-effects of anisodamine and neostigmine in animal models of endotoxic and hemorrhagic shock. Methods: Kunming mice were injected with lipopolysaccharide (LPS $30 \mathrm{mg} / \mathrm{kg}$, ip) to induce endotoxic shock. Anisodamine (12.5, 25, and $50 \mathrm{mg} / \mathrm{kg}$, ip) and neostigmine $(12.5,25$, and $50 \mu \mathrm{g} / \mathrm{kg}$, ip) were administered immediately after LPS injection. Survival rate was monitored, and the serum levels of TNF- $\alpha$ and IL-1 $\beta$ were analyzed using ELISA assays. The effects of anisodamine and neostigmine were also examined in $\alpha 7$ nicotinic acetylcholine receptor ( $\alpha 7 \mathrm{nAChR}$ ) knockout mice with endotoxic shock and in Beagle dogs with hemorrhagic shock.

Results: In mice with experimental endotoxemia, combined administration of anisodamine and neostigmine significantly increased the survival rate and decreased the serum levels of inflammatory cytokines, as compared to those produced by either drug alone. The antishock effect of combined anisodamine and neostigmine was abolished in $\alpha 7 \mathrm{nAChR}$ knockout mice. On the other hand, intravenous injection of the combined anisodamine and neostigmine, or the selective $\alpha 7$ nAChR agonist PNU282987 exerted similar anti-shock effects in dogs with hemorrhagic shock.

Conclusion: The results demonstrate that combined administration of anisodamine and neostigmine produces significant anti-shock effects, which involves activation of $\alpha 7$ nAChRs.
\end{abstract}

Keywords: anisodamine; neostigmine; PNU282987; $\alpha 7$ nicotinic acetylcholine receptor; endotoxic shock; hemorrhagic shock

Acta Pharmacologica Sinica (2012) 33: 761-766; doi: 10.1038/aps.2012.26; published online 14 May 2012

\section{Introduction}

Anisodamine (6-[s]hydroxyhyoscyamine) is a naturally occurring tropane alkaloid found in some plants within the Solanaceae family ${ }^{[1]}$. It is an anticholinergic drug that does not cross into the central nervous system and is widely used clinically in China for various types of shock, especially septic shock ${ }^{[2,3]}$. The mechanisms of anisodamine's beneficial effects on septic shock are mainly attributed to its amelioration of blood flow in the microcirculation. However, the molecular mechanisms of these effects remain unclear ${ }^{[4,5]}$. Recently, a study conducted in this laboratory demonstrated that the anti-shock effects of anisodamine occur mainly via activation of the a7 nicotinic acetylcholine receptor $(\mathrm{a} 7 \mathrm{nAChR})^{[6]}$.

The central nervous system regulates the production of

\footnotetext{
\# These two authors contributed equally to this work.

* To whom correspondence should be addressed.

E-mail wanlc2004@yahoo.com.cn (Chong LIU); dfsu2008@gmail.com (Ding-feng SU)

Received 2011-12-19 Accepted 2012-02-29
}

proinflammatory cytokines through the efferent vagus nerve, termed the "cholinergic anti-inflammatory pathway" ${ }^{\prime 7,8]}$. Acetylcholine, the principal neurotransmitter of the vagus nerve, inhibits the production of proinflammatory cytokines from endotoxin-stimulated macrophages through the $\mathrm{a} 7 \mathrm{nACh} \mathrm{R}^{[9-11]}$. Studies have shown that activation of the a7nAChR-dependent cholinergic anti-inflammatory pathway can control the production of proinflammatory cytokines in experimental models of endotoxic shock and hemorrhagic shock ${ }^{[12,13]}$. Our previous studies have shown that anisodamine blocks muscarinic receptors and promotes increased endogenous acetylcholine binding to the $a 7 \mathrm{nAChR}{ }^{[6]}$.

To produce therapeutic effects, a very large dose of anisodamine must be administered. Neostigmine is a cholinesterase inhibitor that increases endogenous acetylcholine. It is reasonable to speculate that combining anisodamine and neostigmine could augment anti-shock efficacy through activation of the $\alpha 7 \mathrm{nAChR}$-dependent cholinergic anti-inflammatory pathway. In addition, the side effects of neostigmine may be antagonized by blocking muscarinic receptors. To test this 
hypothesis, we carried out a series of experiments in a murine endotoxic shock model and a dog hemorrhagic shock model.

\section{Materials and methods}

\section{Animals and agents}

Kunming mice (22-28 g) and Beagle dogs (8-10 kg) were purchased from Sino-British SIPPR/BK Laboratory Animal Ltd (Shanghai, China). Mice deficient in the $a 7 n A C h R$ were purchased from Jackson Laboratory (B6.129S7-Chrna7tm1Bay, Stock Number: 003232, Bar Harbor, MA, USA). All animals were maintained at $22^{\circ} \mathrm{C}$ under a 12/12-h light/dark cycle and had free access to water and a standard diet. All experimental procedures were approved by the local ethics committee.

Anisodamine hydrochloride was obtained from Fu-Ma Chemical and Engineering Company (Hangzhou, China). Neostigmine methylsulphate was obtained from San-Wei Pharmaceutical Company (Shanghai, China). LPS was purchased from Sigma (Escherichia coli, 0111:B4, St Louis, MO, USA).

\section{Hemorrhagic shock model}

Hemorrhagic shock was induced according to a protocol by Bruegger and colleagues ${ }^{[14]}$. Briefly, animals were anesthetized with sodium pentobarbital $(30 \mathrm{mg} / \mathrm{kg}$, iv), and an endotracheal tube was inserted to maintain normocapnia. A 16-gauge Teflon arterial catheter was inserted into the femoral artery for bloodletting to induce hemorrhagic shock and to measure mean arterial blood (MAP). A polyethylene tube was placed into the femoral vein for drug delivery. After completing the surgical preparation, a 30-min stabilization period began. Subsequently, hemorrhagic shock was initiated by stepwise withdrawal of blood from the femoral artery. MAP was reduced to $45 \mathrm{mmHg}$ within $15 \mathrm{~min}$. This blood pressure was maintained for $30 \mathrm{~min}$ by re-infusing heparinized blood with an automated device. Sham hemorrhagic-shock dogs underwent all surgical procedures without bleeding.

\section{Effects of combining anisodamine/neostigmine on survival rate} in LPS-induced shock mice

Mice received $30 \mathrm{mg} / \mathrm{kg}$ LPS (ip), followed by saline, anisodamine (12.5-50 mg/kg, ip, $n=20$ per group), neostigmine (12.5-50 $\mathrm{gg} / \mathrm{kg}$, ip, $n=20$ per group) or a combination of anisodamine and neostigmine ( $n=20$ per group). In another set of experiments, the mice were challenged with LPS (30 $\mathrm{mg} / \mathrm{kg}$, ip), followed by saline or anisodamine/neostigmine combined ( $25 \mathrm{mg} / \mathrm{kg}$ and $25 \mu \mathrm{g} / \mathrm{kg}$, ip, $n=20$ per group) at 0,3 , and $6 \mathrm{~h}$. Survival rate was monitored for $72 \mathrm{~h}$. During the observation period, the animals were maintained at $22^{\circ} \mathrm{C}$ on a 12-h light/dark cycle and had free access to water and a standard diet.

Effects of combining anisodamine/neostigmine on serum cytokines in LPS-induced shock mice

Blood was collected 90 min after the LPS challenge for the TNF- $\alpha$ assay and at $4 \mathrm{~h}$ after LPS for the IL-1 $\beta$ assay. Serum
TNF- $\alpha /$ IL-1 $\beta$ levels were determined using standard ELISA assays (R\&D Systems, Minneapolis, MN, USA).

Effects of combining anisodamine/neostigmine on survival rate in $\alpha 7 n A C h R$ knockout mice challenged with LPS

The genotypes of the animals were confirmed by polymerase chain reaction (PCR) according to a protocol by Jackson Laboratory (Figure 1). a7nAChR knockout mice or wild-type controls (10 weeks of age) received LPS (20 mg/kg, ip), followed by saline or anisodamine/neostigmine combined $(25 \mathrm{mg} / \mathrm{kg}$ and $25 \mu \mathrm{g} / \mathrm{kg}$, ip, $n=15)$. Survival rate was monitored for $72 \mathrm{~h}$.

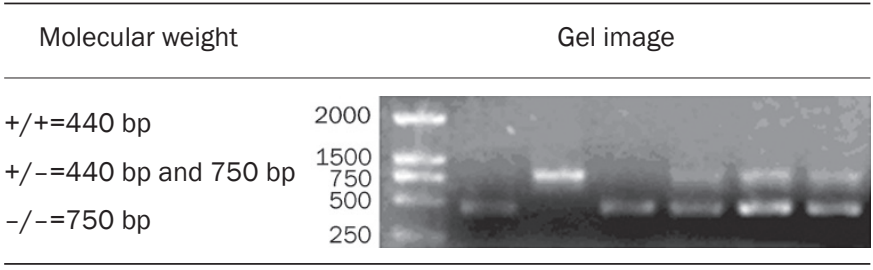

Figure 1. PCR results of the $\alpha 7 n A C h R$ knockout mice and wild-type mice.

Effects of combining anisodamine/neostigmine on serum TNF- $\alpha$ in hemorrhagic shock dogs

Beagle dogs were subjected to hemorrhagic shock and then received saline, anisodamine $(2.63 \mathrm{mg} / \mathrm{kg}$, iv $)$ plus neostigmine $(5.25 \mu \mathrm{g} / \mathrm{kg}, \mathrm{iv})$, or PNU282987 (a selective a7nAChR agonist, $3.37 \mathrm{mg} / \mathrm{kg}$, iv) $(n=6)$. A separate group of dogs $(n=6)$ receiving sham operations were also included for comparison. Blood was collected $20 \mathrm{~min}$ after the drug treatment for the TNF-a assay.

Effects of combining anisodamine/neostigmine on hepatic injury in hemorrhagic shock dogs

Liver tissue specimens were collected at the end of Experiment 4 , rinsed with saline, fixed in $4 \%$ paraformaldehyde for $24 \mathrm{~h}$, and embedded in paraffin. Tissue sections $(2 \mu \mathrm{m})$ were stained with hematoxylin and eosin (H\&E) using a routine protocol, and examined under a light microscope ${ }^{[15]}$.

Effects of combining anisodamine/neostigmine on hemodynamics and survival rate in hemorrhagic shock dogs

Beagle dogs were subjected to hemorrhagic shock and then received saline, anisodamine $(2.63 \mathrm{mg} / \mathrm{kg}$, iv $)$ plus neostigmine $(5.25 \mu \mathrm{g} / \mathrm{kg}$, iv), or PNU282987 (3.37 mg/kg, iv) $(n=6)$. A separate group of dogs $(n=6)$ receiving sham operations were also included for comparison. Blood pressure was monitored for 60 min following drug treatment in hemorrhagic dogs. Survival rate was monitored for $2 \mathrm{~h}$. MAP was only calculated over the first $60 \mathrm{~min}$ since death started to occur at $60 \mathrm{~min}$.

\section{Statistical analysis}

Data involving two groups were analyzed with Student's $t$-tests. For experiments involving more than two groups, the 
data were analyzed with a one-way ANOVA, followed by the Dunnett's $t$-test for multiple comparisons. Serial data of MAP were analyzed with a repeated measures ANOVA. Survival rate was examined using the Kaplan-Meier analysis followed by a Cox regression test. All of the data are expressed as the mean \pm SD. Statistical significance was set at $P<0.05$.

\section{Results}

Effects of combining anisodamine/neostigmine on survival rate in LPS-induced shock mice

In response to a lethal dose of LPS, all mice displayed decreased activity, piloerection, periocular discharge, and diarrhea. The survival rate at $72 \mathrm{~h}$ was $23 \%$. Anisodamine $(12.5,25$, and $50 \mathrm{mg} / \mathrm{kg})$ increased the survival rate to $56 \%$, $64 \%, 56 \%$, respectively. Neostigmine $(12.5,25$, and $50 \mu \mathrm{g} / \mathrm{kg})$ increased the survival rate to $52 \%, 64 \%$, and $72 \%$, respectively. Combining anisodamine/neostigmine $(12.5 \mathrm{mg} / \mathrm{kg}$ and 25 $\mu \mathrm{g} / \mathrm{kg}$ ) increased the survival rate to $83 \%$. An increased dose of the combined treatment $(25 \mathrm{mg} / \mathrm{kg}$ and $25 \mu \mathrm{g} / \mathrm{kg}$ ) increased the survival rate to $92 \%$ (Table 1 and Figure 2). When given 3 and $6 \mathrm{~h}$ after LPS exposure, the combined treatment (25 $\mathrm{mg} / \mathrm{kg}$ and $25 \mu \mathrm{g} / \mathrm{kg}$ ) increased the survival rate to $78 \%$ and $82 \%$ (Figure 3 ). When treatment was delayed for $12 \mathrm{~h}$, no significant reduction in mortality was achieved (data not shown).

Table 1. Effects of anisodamine and neostigmine on survival rate in LPS-induced endotoxic shock mice. Mice were injected with LPS (30 $\mathrm{mg} / \mathrm{kg}$, ip), followed by saline, anisodamine $(12.5,25$, and $50 \mathrm{mg} / \mathrm{kg}$, ip), neostigmine $(12.5,25$, and $50 \mu \mathrm{g} / \mathrm{kg}$, ip), or a combination of anisodamine and neostigmine. Survival rate was monitored for the ensuing 72 h. $n=20$ per group.

\begin{tabular}{ccccc}
\hline \multirow{2}{*}{ Neo $(\mu \mathrm{\mu g} / \mathrm{kg})$} & \multicolumn{4}{c}{ Ani (mg/kg) } \\
& 0 & 12.5 & 25 & 50 \\
\hline 0 & $23 \%$ & $56 \%$ & $64 \%$ & $56 \%$ \\
12.5 & $52 \%$ & $56 \%$ & $76 \%$ & $52 \%$ \\
25 & $64 \%$ & $83 \%$ & $92 \%$ & $56 \%$ \\
50 & $72 \%$ & $67 \%$ & $72 \%$ & $68 \%$ \\
\hline
\end{tabular}

Effects of combining anisodamine/neostigmine on serum cytokine in LPS-induced shock mice

Both anisodamine and neostigmine significantly decreased serum TNF- $\alpha$ and IL-1 $\beta$ in LPS-induced shock mice $(P<0.05$ vs saline control; Figure 4). A combination of anisodamine and neostigmine $(25 \mathrm{mg} / \mathrm{kg}$ and $25 \mu \mathrm{g} / \mathrm{kg}$ ) further decreased serum TNF- $\alpha$ and IL-1 $\beta$ ( $P<0.05$ vs anisodamine or neostigmine alone; Figure 4).

Effects of combining anisodamine/neostigmine on survival rate in $\alpha 7$ nAChR knockout mice challenged with LPS

In wild-type mice, anisodamine/neostigmine combination (25

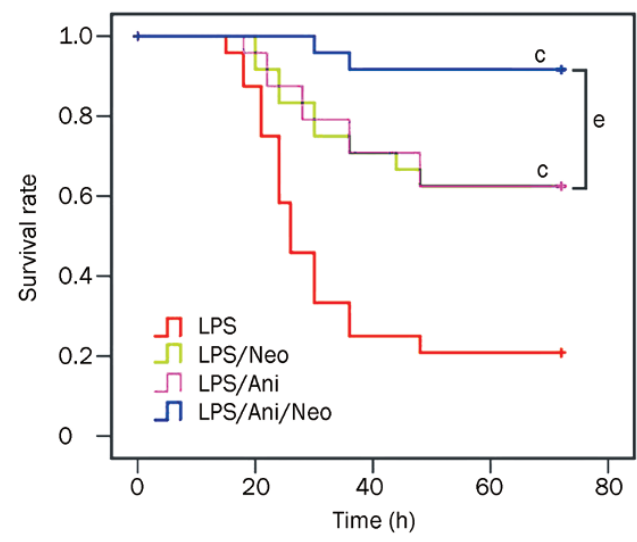

Figure 2. Effects of combining anisodamine and neostigmine on survival rate in LPS-induced endotoxic shock mice. Mice received LPS (30 $\mathrm{mg} / \mathrm{kg}$, ip), followed by vehicle, anisodamine ( $25 \mathrm{mg} / \mathrm{kg}$, ip), neostigmine (25 $\mu \mathrm{g} / \mathrm{kg}$, ip), or a combination of anisodamine $(25 \mathrm{mg} / \mathrm{kg}$, ip) and neostigmine $\left(25 \mu \mathrm{g} / \mathrm{kg}\right.$, ip). $n=20$ per group. ${ }^{\mathrm{c}} P<0.01$ vs LPS; ${ }^{\mathrm{e}} P<0.05$ vs Ani or Neo.

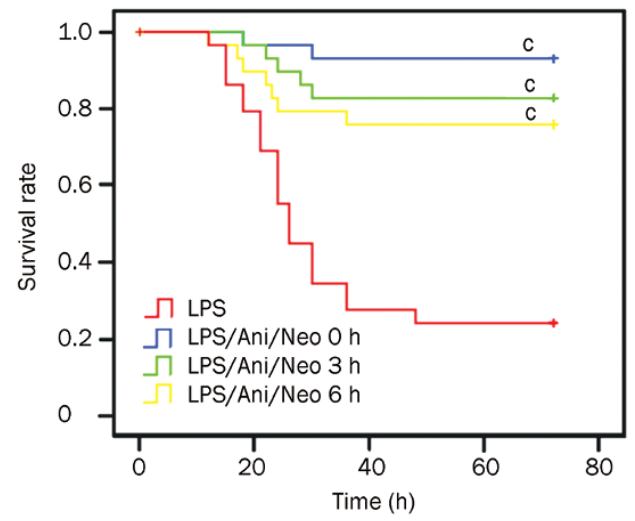

Figure 3. Therapeutic window for combining anisodamine and neostigmine in LPS-induced shock mice. Mice were injected with LPS (30 mg/kg, ip), followed by saline or a combination of anisodamine $(25 \mathrm{mg} / \mathrm{kg}$, ip) and neostigmine $(25 \mu \mathrm{g} / \mathrm{kg}$, ip) at 0,3 , and $6 \mathrm{~h}$ after LPS. Survival rate was monitored for the ensuing 72 h. $n=20$ per group. ${ }^{\circ} P<0.01$ vs LPS.

$\mathrm{mg} / \mathrm{kg}$ and $25 \mu \mathrm{g} / \mathrm{kg}$ ) significantly increased the survival rate ( $90 \%$ vs $42 \%, P<0.01$, Figure $5 \mathrm{~A}$ ). In a7nAChR knockout mice, the combined treatment ( $25 \mathrm{mg} / \mathrm{kg}$ and $25 \mu \mathrm{g} / \mathrm{kg}$ ) did not improve survival rate $(38.5 \%$ vs $15.4 \%, P>0.05$, Figure $5 \mathrm{~B})$.

\section{Effects of combining anisodamine/neostigmine on serum TNF- $\alpha$ in hemorrhagic shock dogs}

Hemorrhagic shock induced a significant increase of serum TNF-a $(P<0.01$ vs sham control). Anisodamine/neostigmine combination significantly decreased serum TNF-a in hemorrhagic shock dogs $(P<0.01$ vs saline control). PNU282987, a selective $a 7 \mathrm{nAChR}$ agonist, also decreased serum TNF-a (Figure 6). 

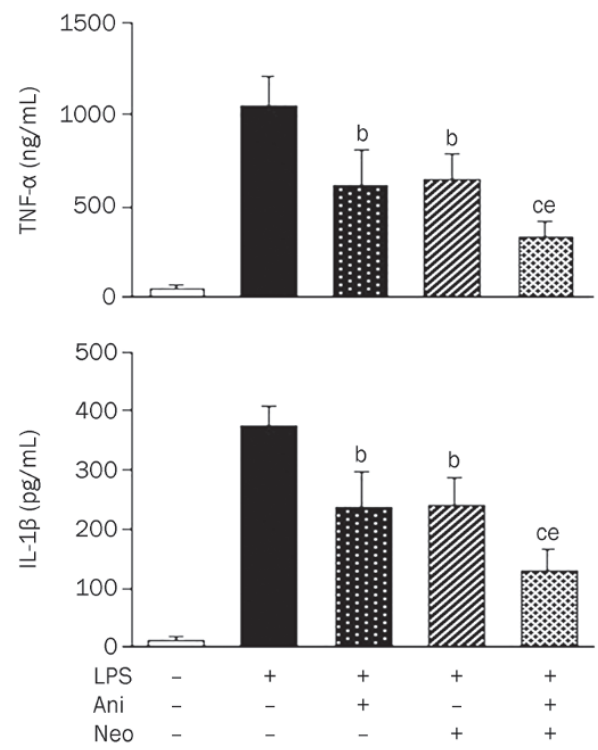

Figure 4. Effects of combining anisodamine and neostigmine on inflammatory cytokines in serum in LPS-induced shock mice. Mice received LPS (30 mg/kg, ip), followed by saline, anisodamine $(25 \mathrm{mg} / \mathrm{kg}$, ip), neostigmine ( $25 \mu \mathrm{g} / \mathrm{kg}$, ip), or a combination of anisodamine (25 $\mathrm{mg} / \mathrm{kg}$, ip) and neostigmine ( $25 \mu \mathrm{g} / \mathrm{kg}$, ip). Blood samples were obtained 90 min later for the TNF- $\alpha$ assay, and $4 \mathrm{~h}$ later for the IL-1 $1 \beta$ assay. $n=8$ per group. ${ }^{\mathrm{b}} P<0.05,{ }^{\mathrm{c}} P<0.01$ vs LPS; ${ }^{\mathrm{e}} P<0.05$ vs Ani or Neo.

\section{Effects of combining anisodamine/neostigmine on hepatic injury in hemorrhagic shock dogs}

Hemorrhagic shock induced significant hepatic damage, eg, widened portal areas, thin fibrous septa, and inflammatory cell infiltration (Figure 7B vs Figure 7A in sham control). It induced bridging or septal fibrosis, connecting portal areas and central veins in a portal-to-portal, portal-to-central, and/or central-to-central pattern. Collagen fibers were clearly visible in the septa. Anisodamine/neostigmine combined ameliorated the damage induced by hemorrhagic shock, decreasing infiltration by inflammatory cells, and putrescence of hepatic cells (Figure 7C). PNU282987 also attenuated the hepatic injury induced by hemorrhagic shock (Figure 7D).

Effects of combining anisodamine/neostigmine on hemodynamics and survival rate in hemorrhagic shock dogs

The combination of anisodamine and neostigmine significantly increased MAP and prolonged survival rate induced by hemorrhagic shock. PNU282987 also increased MAP and survival rate (Figure 8).

\section{Discussion}

The results from the current study demonstrate that the combined use of anisodamine and neostigmine is more effective than either drug alone on controlling inflammation and increased survival rate in LPS-induced shock mice. Remarkably, such treatment was effective even when given 3-6 h after LPS exposure. The combined treatment also alleviated hemorrhagic shock.
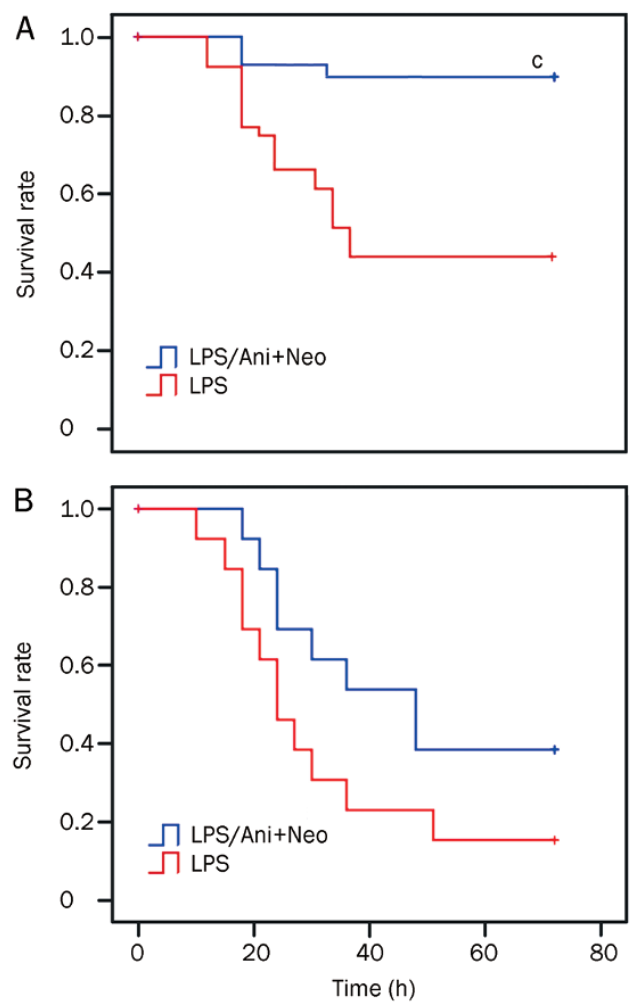

Figure 5. Effects of combining anisodamine and neostigmine on survival rate in $\alpha 7 n$ AChR knockout mice challenged with LPS. $\alpha 7 n A C h R$ knockout mice (B) or wild-type mice (A) received LPS (20 mg/kg, ip), followed by saline or a combination of anisodamine ( $25 \mathrm{mg} / \mathrm{kg}$, ip) and neostigmine (25 $\mu \mathrm{g} / \mathrm{kg}$, ip). Survival rate was monitored for the ensuing $72 \mathrm{~h} . \quad n=15$ per group. ${ }^{c} P<0.01$ vs LPS.

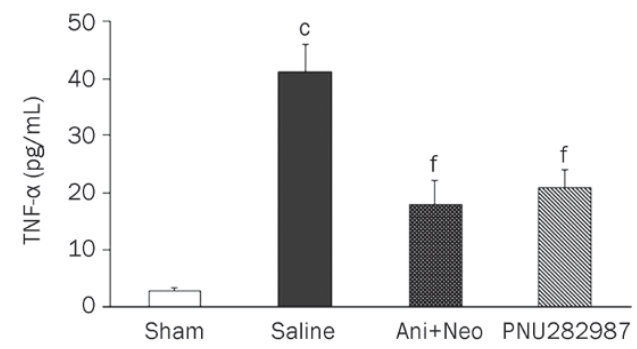

Figure 6. Effects of combining anisodamine and neostigmine on serum TNF- $\alpha$ in hemorrhagic shock dogs. Hemorrhagic shock was induced by gradient bloodletting until the mean arterial pressure was stabilized at 45 $\mathrm{mmHg}$, followed by saline or a combination of anisodamine $(2.63 \mathrm{mg} / \mathrm{kg}$, iv) and neostigmine $(5.25 \mu \mathrm{g} / \mathrm{kg}$, iv) or PNU282987 (3.37 mg/kg, iv). Blood samples were collected $20 \mathrm{~min}$ after treatment. $n=6$ per group. ${ }^{\mathrm{c}} P<0.01$ vs Sham; ${ }^{\mathrm{f}} P<0.01$ vs Saline.

The cholinergic anti-inflammatory pathway has been increasingly implicated in inflammatory diseases, including endotoxic shock. Activation of this anti-inflammatory pathway can be achieved by the following: 1) direct stimulation of the vagus nerve $\left.{ }^{[16,17]}, 2\right)$ the use of nicotine or nicotinic agonists 

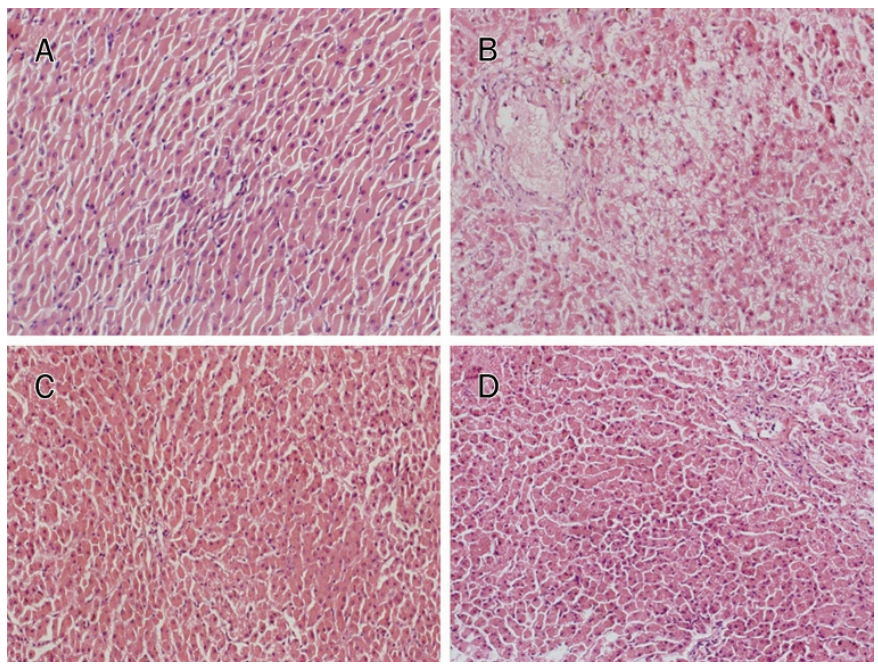

Figure 7. Effects of combining anisodamine and neostigmine on hepatic injury in hemorrhagic shock dogs. (A) Sham control. Light micrographs showing hepatic tissue appeared normal; (B) Hemorrhagic shock. The hemorrhagic shock operation resulted in widened portal areas, thin fibrous septa throughout the hepatic parenchyma, and inflammatory cell infiltration; (C) Anisodamine (2.63 mg/kg, iv) and neostigmine (5.25 $\mu \mathrm{g} / \mathrm{kg}$, iv) and (D) PNU282987 (3.37 mg/kg, iv). Both anisodamine/ neostigmine combined and PNU282987 treatment produced less infiltration by inflammatory cells, and less putrescence of hepatic cells. $n=6$ per group. Magnification: $200 \times$.
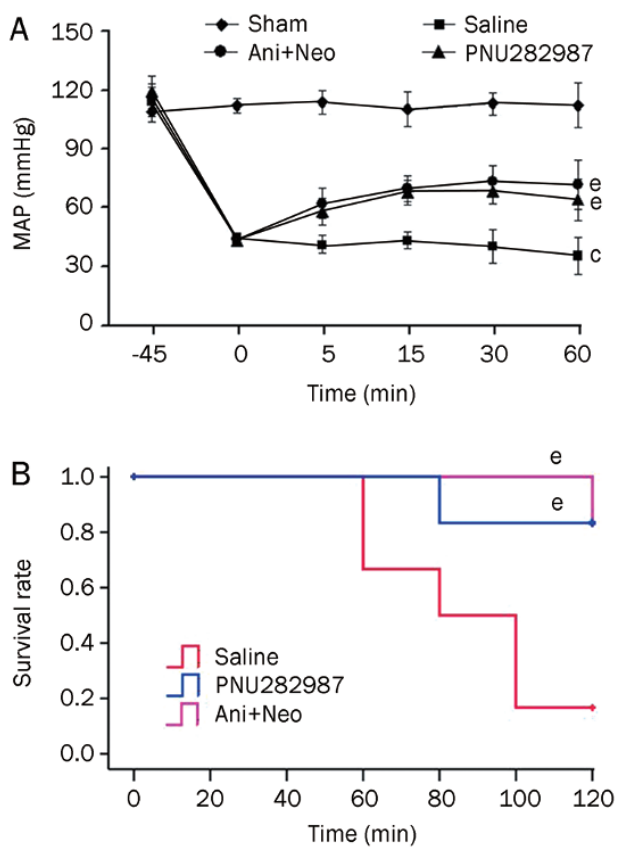

Figure 8. Effects of combined anisodamine and neostigmine on MAP and survival rate in hemorrhagic shock dogs. Hemorrhagic shock was induced by gradient bloodletting until the mean arterial pressure was stabilized at $45 \mathrm{mmHg}$, followed by saline or a combination of anisodamine (2.63 $\mathrm{mg} / \mathrm{kg}$, iv) and neostigmine $(5.25 \mu \mathrm{g} / \mathrm{kg}$, iv) or PNU282987 (3.37 mg/kg, iv). $n=6$ per group. (A) MAP was calculated over the first 60 min. ${ }^{\circ} P<0.01$ vs Sham; ${ }^{e} P<0.05,{ }^{\text {f }} P<0.01$ vs Saline. (B) Survival rate was monitored for the ensuing $2 \mathrm{~h} .{ }^{\mathrm{e}} \mathrm{P}<0.05$ vs Saline.
(GTS-21, CAP55) to activate the $a 7 \mathrm{nAChR}{ }^{[18-20]}$, and 3) the use of cholinesterase inhibitors (physostigmine, galantamine) ${ }^{[21-23]}$. Our previous studies demonstrated that anisodamine could produce anti-inflammatory actions through indirectly activating the a7nAChR. Here, we examined the anti-shock effects of combining anisodamine/neostigmine and found that the combination of anisodamine and neostigmine could produce robust anti-shock effects even at small doses. Combining anisodamine/neostigmine significantly decreased serum TNF- $\alpha$ and IL-1 $\beta$ and improved the survival rate in LPS-induced shock mice. In a7nAChR knockout mice, the combined treatment did not improve the survival rate, suggesting that the beneficial effects of combining anisodamine/neostigmine on endotoxic shock is mediated primarily by the a7nAChR.

The initial presentation of endotoxic shock is often nonspecific, and its severity is concealed ${ }^{[24,25]}$. Patients who arrive at the ICU with a seemingly benign infection can progress within hours to a devastating condition ${ }^{[26,27]}$. A delay in the diagnosis and management of critically ill patients during the first six hours of ICU admission has been associated with higher mortality rates and increased utilization of hospital resources ${ }^{[28,29]}$. Based on this finding, the concept of 'golden hours' is widely acknowledged ${ }^{[30,31]}$. In the present study, we found that the combined treatment of anisodamine and neostigmine could significantly improve survival rate in animals, even 3-6 h after LPS exposure. This finding extends the window of treatment following LPS administration and may have clinical relevance. Inflammatory cytokines plays an important role in acute hypovolemic hemorrhagic shock because anti-TNF-a monoclonal antibodies could increase survival, improve hypotension, and attenuate impairment in vascular reactivity ${ }^{[32]}$. Recent studies have demonstrated that electrical stimulation of efferent vagal fibers could rapidly reverse hypotension, counteract hepatic NF-KB activation, reduce TNF- $\alpha$ plasma levels and improve survival rate in experimental hemorrhagic shock rats ${ }^{[13,33]}$. Systemic administration of an acetylcholinesterase inhibitor also improves outcomes after hemorrhagic shock ${ }^{[22]}$. In our study, combining anisodamine and neostigmine markedly decreased serum TNF- $\alpha$ and prevented organ damage (as exemplified by the liver results presented here) induced by hemorrhagic shock. The combined treatment also improved hypotension and prolonged the survival rate in hemorrhagic shock dogs. PNU282987, a selective a7nAChR agonist, had similar effects, suggesting the involvement of the a7nAChR.

Several methods can be used to activate the cholinergic anti-inflammatory pathway. However, much work needs to be performed to successfully apply these methods in clinical practice. Anisodamine and neostigmine are both used in clinical practice. We believe that, if titrated properly and carefully, an anisodamine/neostigmine cocktail may be clinically useful.

In summary, this study demonstrated that combining anisodamine and neostigmine could increase the survival rate in a murine endotoxic shock model and a dog hemorrhagic shock model through activation of the cholinergic anti-inflammatory pathway. Our findings may have important implications toward the development of new treatment strategies for endo- 
toxic shock, hemorrhagic shock and other inflammatory diseases.

\section{Acknowledgements}

This study was supported by the National Natural Science Foundation of China (30900529).

\section{Author contribution}

Li SUN, Gu-fang ZHANG, and Xin ZHANG performed the mouse experiments; Qing LIU and Jian-guo LIU performed the dog experiments; Ding-feng SU designed the research; Qing LIU and Chong LIU designed the research, analyzed the data and wrote the paper.

\section{References}

1 Poupko JM, Baskin SI, Moore E. The pharmacological properties of anisodamine. J Appl Toxicol 2007; 27: 116-21.

2 Wang ST, Kuo NL. Experience in emergency treatment of shock due to infection. Chin Med J 1978; 6: 497-500.

3 Xiu RJ. Studies on microcirculation in the Institute of Basic Medical Sciences, Chinese Academy of Medical Sciences. Microvasc Res 1980; 20: 371-3.

4 Varma DR, Yue TL. Adrenoceptor blocking properties of atropinelike agents anisodamine and anisodine on brain and cardiovascular tissues of rats. Br J Pharmacol 1986; 87: 587-94.

5 Zhang WW, Song MK, Cui YY, Wang H, Zhu L, Niu YY, et al. Differential neuropsychopharmacological influences of naturally occurring tropane alkaloids anisodamine versus scopolamine. Neurosci Lett 2008; 443: 241-5.

6 Liu C, Shen FM, Le YY, Kong Y, Liu X, Cai GJ, et al. Antishock effect of anisodamine involves a novel pathway for activating alpha7 nicotinic acetylcholine receptor. Crit Care Med 2009; 37: 634-41.

7 Borovikova LV, Ivanova S, Zhang M, Yang H, Botchkina GI, Watkins LR, et al. Vagus nerve stimulation attenuates the systemic inflammatory response to endotoxin. Nature 2000; 405: 458-62.

8 Wang H, Yu M, Ochani M, Amella CA, Tanovic M, Susarla S, et al. Nicotinic acetylcholine receptor alpha 7 subunit is an essential regulator of inflammation. Nature 2003; 421: 384-8.

9 Tattevin P, Monnier D, Tribut O, Dulong J, Bescher N, Mourcin F, et al. Enhanced indoleamine 2,3-dioxygenase activity in patients with severe sepsis and septic shock. J Infect Dis 2010; 201: 956-66.

10 Lavoie PM, Huang Q, Jolette E, Whalen M, Nuyt AM, Audibert F, et al. Profound lack of interleukin (IL)-12/IL-23p40 in neonates born early in gestation is associated with an increased risk of sepsis. $J$ Infect Dis 2010; 202: 1754-63.

11 Zhang XH, Lei H, Liu AJ, Zou YX, Shen FM, Su DF. Increased oxidative stress is responsible for severer cerebral infarction in stroke-prone spontaneously hypertensive rats. CNS Neurosci Ther 2011; 17: 5908.

12 Wang $\mathrm{H}$, Liao $\mathrm{H}$, Ochani M, Justiniani M, Lin X, Yang L,et al. Cholinergic agonists inhibit HMGB1 release and improve survival in experimental sepsis. Nat Med 2004; 10: 1216-21.

13 Guarini S, Altavilla D, Cainazzo MM, Giuliani D, Bigiani A, Marini H, et al. Efferent vagal fiber stimulation blunts nuclear factor-kappa $\mathrm{B}$ activation and protects against hypovolemic hemorrhagic shock. Circulation 2003; 107: 1189- 94.

14 Bruegger D, Kemming GI, Jacob M, Meisner FG, Wojtczyk CJ, Packert $\mathrm{KB}$, et al. Causes of metabolic acidosis in canine hemorrhagic shock: role of unmeasured ions. Crit Care 2007; 11: R130.

15 Liu C, Zhang GF, Song SW, Cai GJ, Liu WH, Miao CY, et al. Effects of ketanserin on endotoxic shock and baroreflex function in rodents. J Infect Dis 2011; 204: 1605-12.

16 Bernik TR, Friedman SG, Ochani M, DiRaimo R, Ulloa L, Yang H, et al. Pharmacological stimulation of the cholinergic antiinflammatory pathway. J Exp Med 2002; 195: 781-8.

17 Li M, Zheng C, Sato T, Kawada T, Sugimachi M, Sunagawa K. Vagal nerve stimulation markedly improves long-term survival after chronic heart failure in rats. Circulation 2004; 109: 120-4.

18 Pavlov VA, Ochani M, Yang LH, Gallowitsch-Puerta M, Ochani K, Lin X, et al. Selective alpha7-nicotinic acetylcholine receptor agonist GTS21 improves survival in murine endotoxemia and severe sepsis. Crit Care Med 2007; 35: 1139-44.

19 Van Westerloo DJ, Giebelen IA, Florquin S, Bruno MJ, Larosa GJ, Ulloa L, et al. The vagus nerve and nicotinic receptors modulate experimental pancreatitis severity in mice. Gastroenterology 2006; 130: 1822-30.

20 Martin LF, Kem WR, Freedman R. Alpha-7 nicotinic receptor agonists: potential new candidates for the treatment of schizophrenia. Psychopharmacology 2004; 174: 54-64.

21 Hofer S, Eisenbach C, Lukic IK, Schneider L, Bode K, Brueckmann M, et al. Pharmacologic cholinesterase inhibition improves survival in experimental sepsis. Crit Care Med 2008; 36: 404-8.

22 Mathis KW, Sulzer J, Molina PE. Systemic administration of a centrally acting acetylcholinesterase inhibitor improves outcome from hemorrhagic shock during acute alcohol intoxication. Shock 2010; 34: 162-8.

23 Pavlov VA, Parrish WR, Rosas-Ballina M, Ochani M, Puerta M, Ochani $\mathrm{K}$, et al. Brain acetylcholinesterase activity controls systemic cytokine levels through the cholinergic anti-inflammatory pathway. Brain Behav Immun 2009; 23: 41-5.

24 Dellinger RP, Carlet JM, Masur H, Gerlach H, Calandra T, Cohen J, et al. Surviving Sepsis Campaign guidelines for management of severe sepsis and septic shock. Crit Care Med 2004; 32: 858-72.

25 American college of chest physicians/society of critical care medicine consensus conference: definitions for sepsis and organ failure and guidelines for the use of innovative therapies in sepsis. Crit Care Med 1992; 20: 864-74.

26 Rivers EP, McIntyre L, Morro DC, Rivers KK. Early and innovative interventions for severe sepsis and septic shock: taking advantage of a window of opportunity. CMAJ 2005; 173: 1054-65.

27 Rivers E, Nguyen B, Havstad S, Ressler J, Muzzin A, Knoblich B, et al. Early goal-directed therapy in the treatment of severe sepsis and septic shock. N Engl J Med 2001; 345: 1368-77.

28 Lundberg JS, Perl TM, Wiblin T, Costigan MD, Dawson J, Nettleman $\mathrm{MD}$, et al. Septic shock: an analysis of outcomes for patients with onset on hospital wards versus intensive care units. Crit Care Med 1998; 26: 1020-4.

29 Engoren M. The effect of prompt physician visits on intensive care unit mortality and cost. Crit Care Med 2005; 33: 727-32.

30 Blow O, Magliore L, Claridge JA, Butler K, Young JS. The golden hour and the silver day: detection and correction of occult hypoperfusion within 24 hours improves outcome from major trauma. J Trauma 1999; 47: 964-9.

31 Bledsoe BE. The Golden Hour: fact or fiction? Emerg Med Serv 2002; 31: 105.

32 Squadrito F, Altavilla D, loculano M, Calapai G, Zingarelli B, Saitta A, et al. Passive immunization with antibodies against tumor necrosis factor (TNF- $\alpha$ ) protects from the lethality of splanchnic artery occlusion shock. Circ Shock 1992; 37: 236-44.

33 Guarini S, Cainazzo MM, Giuliani D, Mioni C, Altavilla D, Marini H, et al. Adrenocorticotropin reverses hemorrhagic shock in anesthetized rats through the rapid activation of a vagal anti-inflammatory pathway. Cardiovasc Res 2004; 63: 357-65. 